\title{
Characteristic and Distribution of Congenital Heart Disease in Outpatient Clinic and Paediatric Ward of Dr. Soedono Hospital Madiun 2015
}

\author{
Finariawan ${ }^{1, *}$, Syifa Mahmud S.A \\ ${ }^{1}$ Department of Paediatric, dr. Soedono Hospital Madiun - Faculty of Medicine, Universitas Islam Indonesia, Yogyakarta, \\ Indonesia \\ ${ }^{2}$ Staff Faculty of Medicine, Universitas Islam Indonesia, Yogyakarta, Indonesia \\ *correspondence: sheva_smuth@yahoo.com
}

\begin{abstract}
Background: Congenital heart disease is a heart abnormality that present at birth and most commonly caused death among other congenital defect. Congenital heart disease affecting up to 8-10 in every 1000 newborn. With number of birth around 4,5 billion per year, there are approximately 40.000 babies born with congenital heart disease in Indonesia.

Research method: This was a descriptive research about the characteristic and distribution of congenital heart disease at ward and clinic of RSUD dr. Soedono Madiun, East Java for a year, by investigating medical record from 1 January 2015 - 31 December 2015. The patient grouped by age, gender, type of congenital heart disease, aged when first diagnosed, nutritional status, other diseases coming with congenital heart disease,medical intervention to treat the condition, and the payment method. The data analyzed to know the number from each aspect.

Result: Total sample from this research was 49 sampel, consist of $53,06 \%$ male, and $46,94 \%$ female. The condition mostly found at the first year of life $(75,51 \%)$ and $75,51 \%$ diagnosed as acyanotic congenital heart disease. Malnutrition found in $51,02 \%$ of sample. Non surgical medical intervention is the most management done to treat the condition $(97,67 \%)$. The payment with BPJS (PBI or non PBI) used in more than half of the sample $(51,02 \%)$. Conclusion :Congenital heart disesase mostly found at the first year of life. Number of Acyanotic congenital heart disease more than cyanotic congenital heart disease. More than half of the sample considered malnutrition. Non surgical intervention is the most management chosen to treat the condition. National Health insurance by BPJS only cover up to $51,02 \%$ of the sample.
\end{abstract}

Keywords : congenital heart disease; characteristic distribution; children 